Research, part of a Special Feature on Ecological Restoration in Northern Regions

\title{
Cultivating Communication: Participatory Approaches in Land Restoration in Iceland
}

\author{
Brita Berglund $^{1}$, Lars Hallgren ${ }^{2}$ and Ása L. Aradóttir ${ }^{1}$
}

\begin{abstract}
Stakeholder participation in environmental management is increasing. Staff of environmental agencies, however, often lack training in communication and in conducting participatory processes. Their interpretation of "participation" is of interest because interpretation affects how participation is practiced. We explored how participation was interpreted within the Soil Conservation Service of Iceland and how the interpretation affected how participation was carried out in two land restoration projects. Our methods included semi-structured interviews with agency staff and involved stakeholders, participant observations, and document review. The findings showed that participation was seen as a method to accomplish the agency's tasks, and the focus was primarily on the outputs, or products, of the participatory processes. This interpretation worked well and created positive outcomes as long as process factors, such as interaction with other stakeholders and shared influence, were adequately attended to and joint gains were assured, but other stakeholders expressed dissatisfaction when they were not. We conclude that, although tangible outcomes are necessary for environmental agencies, maintaining a balance between product and process focus in participatory projects is important for optimal results. To increase their ability to deal with process factors, environmental agencies, and ultimately environmental management, would benefit from enhancing their personnel's understanding of participation, and capacity to conduct participatory processes. To facilitate participation, this understanding should also be integrated in the institutional framework the agencies work within.
\end{abstract}

Key Words: environmental management; influence; interaction; interpretation of participation; joint gains; land restoration; participatory approaches; participatory processes

\section{INTRODUCTION}

Stakeholder participation is now widely encouraged in environmental management (Reed 2008). One reason is an increased awareness that the "old" top-down and expertdriven approaches are inadequate for dealing with complex environmental issues (Campbell 1994, Pretty 1995, Buchy and Hoverman 2000, Beierle 2002, Reed 2008). Instead, knowledge, ideas, interests, and values of a wide range of stakeholders are needed to ensure the contemporary ideal of sustainability. This is reflected in several international conventions, e.g., the Convention on Biological Diversity (1991) and the Aarhus Convention (UNECE 1998), and is also evident in policies and practice (Buchy and Hoverman 2000, Moore et al. 2001, Senecah 2004, Stenseke 2009). An increasing number of environmental agencies are therefore either required to use participatory approaches or decide themselves to try this alternative way. Participation, however, is an ambiguous concept (Buchy and Hoverman 2000, Westberg et al. 2010), which makes it difficult to operationalize. Furthermore, the personnel of traditional topdown organizations seldom have formal training in communication (Campbell 1994, Stenseke 2009, Westberg et al. 2010), and participation is often in radical contrast to their previous knowledge and experiences. So what happens when they start involving other stakeholders?
According to Blumer (1969:2), "human beings act toward things [including guiding ideals] on the basis of the meanings that the things have for them," and the meanings themselves are developed and modified through social interaction. Thus, agency personnel would be expected to practice "participation" on the basis of their interpretation of the concept, i.e., the meaning it has for them, and the interpretation itself would develop through participatory activities. A study of how participatory projects are carried out, and the considerations, actions, and interactions involved, should therefore provide understanding of both interpretation and its effect on how participation is practiced.

The Soil Conservation Service of Iceland (SCSI) started using what they describe as participatory approaches in land restoration on a systematic basis in 1990 (Arnalds 2005). The SCSI is a governmental agency that was established in 1907. Its main task is to halt soil erosion, restore degraded land, and promote sustainable land use. Before 1990, agency staff carried out most soil conservation activities by themselves, with little involvement of farmers and other land users. The general perception was therefore that the government carried the responsibility for soil erosion and conservation. This is also evident in the current soil conservation legislation (Lög um landgræðslu no. 17/1965), which asserts governmental control over soil conservation matters. The agency's top-down

${ }^{1}$ Faculty of Environmental Sciences, Agricultural University of Iceland, ${ }^{2}$ Department of Urban and Rural Development, Swedish University of Agricultural Sciences 
Table 1. Frequently mentioned aims and benefits with participation.

\begin{tabular}{|c|c|}
\hline Pragmatic aims and benefits & Normative aims and benefits \\
\hline Cost efficiency & Fairness, equity, joint gains \\
\hline (Pretty 1995, Beierle 2002) & (Beierle 2002, Rowe and Frewer 2005, Reed 2008) \\
\hline Effectiveness in reaching specific targets & Trust \\
\hline $\begin{array}{l}\text { (Pretty 1995, Moore et al. 2001, Rowe and Frewer 2005, Senecah } \\
\text { 2004) }\end{array}$ & (Buchy and Hoverman 2000, Senecah 2004, Reed 2008 ${ }^{\dagger}$ ) \\
\hline Higher quality outputs & Improved relationships \\
\hline (Senecah 2004, Reed 2008) & $\begin{array}{l}\text { (Pretty 1995, Buchy and Hoverman 2000, Senecah 2004, Reed } \\
2008^{\dagger} \text { ) }\end{array}$ \\
\hline Stakeholder commitment; "ownership" of participatory processes & Democracy, influence, shared control \\
\hline and outcomes. Leads to higher quality and sustainability of outputs & (Arnstein 1969, Pretty 1995, Buchy and Hoverman 2000, Rowe and \\
\hline $\begin{array}{l}\text { (Pretty 1995, Buchy and Hoverman 2000, Moore et al. 2001, Reed } \\
\text { 2008) }\end{array}$ & Frewer 2005, Reed 2008) \\
\hline
\end{tabular}

approaches often led to tension between the SCSI and farmers (Barkarson and Johannsson 2009). Eventually this led to the realization that the agency's old methods were inadequate for dealing with many of the underlying causes and thus for accomplishing its main tasks (Arnalds 2005). Subsequently, the SCSI started to involve other stakeholders in its activities.

We explored how participation was interpreted within the Soil Conservation Service of Iceland and how this interpretation affected how participation was practiced in two land restoration projects. We wanted to know how those involved in what they themselves defined as participation made sense of it in practice, from their internal interpretations. The objective was to learn from the SCSI's experience, with the overall purpose of enhancing participatory processes in land restoration.

\section{Key aspects of participation}

In order to identify interpretations of participation, we first had to establish what constitutes participation. Because we wanted to know how the SCSI staff interpreted the concept, we could not use a pre-existing definition. A literature review, however, suggested some key aspects of participation that informed our analysis: aims, expectations, and gains; influence and control; interaction; and ability and commitment of organizers of participatory projects.

Aims and expectations with participatory projects can be said to reflect how people understand the role of participation. Aims, or expected benefits (Table 1), are often described as either pragmatic, where participation is perceived as a method to achieve a specific outcome, or normative, where participation is seen as an ideology and valuable in itself (Buchy and Hoverman 2000, Beierle 2002, Reed 2008). Pragmatic aims focus on the outputs, or products, of participatory processes, while normative aims are more people-centered (Michener 1998) and relate to how the processes are conducted and experienced (Buchy and Hoverman 2000). All participatory projects involve both product and process considerations, but the emphasis varies. According to Pretty (1995), a process is participatory only if it involves joint gains and positive lasting effects for those involved. In order to be satisfied with a participatory project, stakeholders have to perceive that they gain something (Warburton 1997, Beierle 2002).

A frequently mentioned aspect of participation is influence and shared control, at least to some degree, but a common dilemma is that while most stakeholders expect to have some influence over the participatory process and its outcomes, authorities are often reluctant to release control (Arnstein 1969, Pretty 1995, Buchy and Hoverman 2000).

Interaction, especially two-way communication, is another key aspect, and the more intensive forms, such as dialogue and deliberation, provide opportunities for stakeholders to share ideas, values, and knowledge, and to have real influence (e.g., Pretty 1995, Buchy and Hoverman 2000, Beierle 2002, Senecah 2004, Rowe and Frewer 2005, Stringer et al. 2006).

Failures of participatory projects are often ascribed to initiating organizations' lack of commitment and ability to engage meaningfully in participatory processes (Senecah 2004, Reed 2008), or to their resistance to change (Warburton 1997). Meaningful participation requires project organizers to be willing and able to share responsibility with other stakeholders, and commit themselves to the unpredictable outcomes embedded in participation (Buchy and Hoverman 2000, Reed 2008). An agency's effort to adapt to these requirements is therefore an indicator of its commitment. Other indicators are the amount of time, staff, and other resources allocated to participatory projects (Buchy and Hoverman 2000). 


\section{METHODS}

We chose to focus on the SCSI because they explicitly state that they use participatory approaches (Arnalds 2005, SCSI 2012). We looked at how the SCSI staff made sense of participation, using two land restoration projects as case studies. Because we wanted extensive data, we deliberately selected projects with different approaches to participation. Farmers Heal the Land is an SCSI project, and the agency has been a driving force in the other project, Hekluskógar.

\section{Case studies}

Farmers Heal the Land (FHL) is a cost-share project, inspired by the Landcare movement (Arnalds 2005). Farmers participate in the project on an individual basis and carry out revegetation on their own land, while the SCSI provides extension services, seeds, and funding to cover fertilizer costs. Launched in 1990, it was the first SCSI project to systematically involve other stakeholders. Its purpose was to reach "the long-term goal of making the land users the true custodians of the land" (Arnalds 2005:121). The idea behind FHL was to support an interest in soil conservation already present among farmers. In 2011, about $20 \%$ of Icelandic farms (Farmers Association of Iceland 2010, Brynleifsdóttir 2011) participated in the project (Fig. 1). SCSI district officers, stationed in different parts of the country (Fig. 1), visit all participating farms regularly (Jónsson 2009). During visits, restoration activities are discusses and monitored, but they also provide opportunities for building relations and mutual trust (Arnalds 2005).

Fig. 1. Map of Iceland showing location of farms participating in the Farmers Heal the Land project 2011 (red dots) and district offices of the Soil Conservation Service of Iceland (blue triangles) (S. J. Brynleifsdóttir, Soil Conservation Service of Iceland 2011).

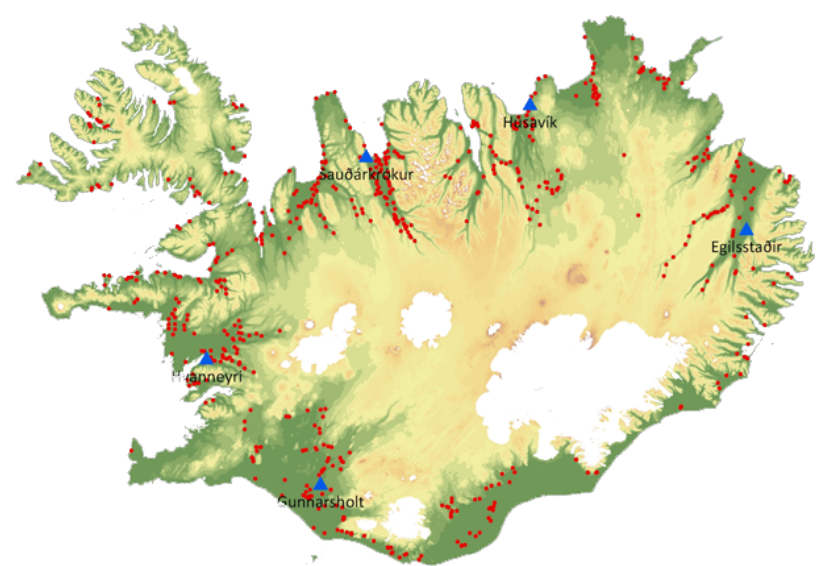

The aim of the Hekluskógar project is to restore native woodlands on about $900 \mathrm{~km}^{2}$ of largely eroded land near Mt. Hekla in south Iceland through revegetation and planting of native tree and shrub species in clusters that later serve as seed sources for natural regeneration (Aradóttir 2007). The project idea was first developed within the SCSI, but in 2005, representatives of local farmers and relevant governmental and nongovernmental organizations were invited to form a collaboration committee for the project (Table 2). The committee took active part in planning and promoting the project until baseline governmental funding was secured in May 2007. Hekluskógar then became an independent governmental project (Hekluskógar 2007), and the collaboration committee's role changed to be mainly advisory. An executive board-since 2010 made up of the directors of two governmental agencies: the SCSI and Iceland Forest Service-is now formally responsible for the project, while a project manager runs the daily activities (Table 2, Hreinn Óskarsson, personal communication). In this study we focused on the collaboration committee.

\section{Data collection and analysis}

The first author conducted 22 semi-structured interviews with SCSI officials and district officers, farmers participating in FHL, and members of the Hekluskógar collaboration committee (Table 3) from April 2011 to February 2012. Four of the interviews were completed by telephone and 18 faceto-face. Mind maps (Buzan and Buzan 2006) with keywords and themes served as interview guides, and the average interview duration was one hour. All interviews were recorded and transcribed word-by-word by the first author.

The first author also made participant observations (Boeije 2010) during district officers' visits to farmers on three separate occasions, each time with a different officer in a different area. Each occasion lasted one full day, and altogether 12 farms were visited. Furthermore, reports from both projects, and contracts and meeting minutes from Hekluskógar were reviewed.

Interview transcripts were analyzed through two approaches described by Kvale (1996): meaning categorization and meaning condensation. The following aspects of participatory processes served as main categories: (1) aims, expectations, and gains, (2) influence and control, (3) interaction, and (4) ability and commitment of project organizers.

\section{FINDINGS}

The main categories are central to the analysis; therefore, relevant findings from both case studies are presented under each category. 
Table 2. Hekluskógar project development and time line.

\begin{tabular}{|c|c|c|c|}
\hline Time & Period & History & $\begin{array}{l}\text { Collaboration committee: role and } \\
\text { frequency of meetings }\end{array}$ \\
\hline-2005 & "Germination phase" & $\begin{array}{l}\text { Project idea originates and is further developed by a } \\
\text { working group within the Soil Conservation Service of } \\
\text { Iceland (SCSI) }\end{array}$ & \\
\hline \multirow[t]{3}{*}{$2005-2007$} & "Collaboration phase" & $\begin{array}{l}\text { Representatives of relevant governmental and } \\
\text { nongovernmental organizations, and groups invited to } \\
\text { collaborate with SCSI on the project } \\
\text { Collaboration committee }{ }^{\dagger} \text { established }\end{array}$ & $\begin{array}{l}\text { Co-ordinate activities, preparation } \\
\text { and planning, promotion of project } \\
\text { in order to get funding, decisions } \\
\text { about project design }\end{array}$ \\
\hline & & $\begin{array}{l}\text { Meeting held in spring } 2005 \text {, where farmers and other } \\
\text { landowners could express ideas and concerns, and appoint } \\
\text { their committee representative }\end{array}$ & $\begin{array}{l}\text { Frequent meetings, up to several } \\
\text { times per month }\end{array}$ \\
\hline & & $\begin{array}{l}\text { Committee appointed several working groups for planning } \\
\text { and promoting the project }\end{array}$ & \\
\hline \multirow[t]{5}{*}{$2007-$} & "Project phase" & $\begin{array}{l}\text { May 2007: Contract for } 10 \text { years of funding signed between } \\
\text { SCSI, Iceland Forest Service, and Ministries of Agriculture } \\
\text { and Finance }\end{array}$ & $\begin{array}{l}\text { New role according to contract: } \\
\text { strategic planning, approval of } \\
\text { yearly executive plans and financial } \\
\text { statements }\end{array}$ \\
\hline & & $\begin{array}{l}\text { Hekluskógar executive board responsible for project. One } \\
\text { representative each from SCSI, Iceland Forest Service, and } \\
\text { the Ministry of Agriculture }\end{array}$ & $\begin{array}{l}\text { At least two meetings to be held per } \\
\text { year according to contract. Annual } \\
\text { general meeting no later than } 31\end{array}$ \\
\hline & & $\begin{array}{l}\text { Project manager in charge of daily activities. Volunteers } \\
\text { involved in tree planting (e.g., summer house owners in } \\
\text { area, only few farmers). Tree plants for free. Farmers' } \\
\text { representative on collaboration committee in charge of } \\
\text { plant distribution }\end{array}$ & $\begin{array}{l}\text { January } \\
\text { Meetings held in reality: } \\
\text { June } 2008 \\
\text { 10 November } 2008 \\
\text { January } 2009\end{array}$ \\
\hline & & $\begin{array}{l}\text { January 2008: Hekluskógar transferred from Ministry of } \\
\text { Agriculture to Ministry of the Environment }\end{array}$ & 10 May 2010 \\
\hline & & $\begin{array}{l}\text { May 2010: Directors of SCSI and Iceland Forest Service } \\
\text { become the only members of the executive board }\end{array}$ & \\
\hline \multicolumn{4}{|c|}{$\begin{array}{l}{ }^{\dagger} \text { The committee members were representatives of the following organizations or groups: SCSI; Iceland Forest Service; Soil Conservation } \\
\text { Fund; South Forests Farmer Project; The Forest Associations of Rangárvallasýsla and Árnessýsla: local farmers of the Hekluskógar area. } \\
\text { (Source: Hekluskógar collaboration committee 2005, Hreinn Óskarsson, personal communication, meeting minutes and other documents } \\
\text { from Hekluskógar.) } \\
\text { "The meetings listed are the collaboration committee meetings held after Hekluskógar became an independent project and before } \\
\text { interviews were conducted with committee members in April-June 2011. Additional meetings might have taken place after that. }\end{array}$} \\
\hline
\end{tabular}

\section{Aims, expectations, and gains}

The SCSI staff expressed mainly pragmatic aims and expectations with FHL (Table 4). Project outcomes matched the expectations of the SCSI staff and participating farmers (Table 4), and both parties were generally satisfied. Many of them pointed out that improved relationships between the SCSI and farmers was a prerequisite for other gains. The following statement by one farmer reflected this view:

"And it is no longer 'us' and 'them,' now ... we talk about 'us'. We are on the same team and working together on tasks, and there is mutual understanding..."
Nevertheless, several interviewees also mentioned examples where farmers had positive relationships with SCSI district officers but still distrusted the agency itself. Another outcome, mentioned by district officers and farmers, was joint creation and accumulation of knowledge about soil conservation matters in the farmer-district officer network. There were, however, no built-in mechanisms in FHL to document this knowledge.

In Hekluskógar, collaboration partners were strategically chosen with the expectation that the support of a larger group of people, mainly with local connections-often called "grassroots" in the interviews-would convince politicians and help 
Table 3. Description of interviewee groups and number of interviews.

\begin{tabular}{|c|c|c|c|}
\hline Interviewee group & $\begin{array}{l}\text { No. of } \\
\text { interviews } \\
(n=22)^{\dagger}\end{array}$ & Description of group & Criteria for choice of interviewees \\
\hline $\begin{array}{l}\text { Soil Conservation Service of } \\
\text { Iceland (SCSI) officials }\end{array}$ & 5 & Director and managers at the SCSI & Relevance to case studies \\
\hline SCSI district officers & 7 & $\begin{array}{l}\text { District officers, stationed at five SCSI district } \\
\text { offices }\end{array}$ & $\begin{array}{l}\text { All current (spring 2011) district } \\
\text { officers with > } 1 \text { year experience }\end{array}$ \\
\hline $\begin{array}{l}\text { Farmers in Farmers Heal the } \\
\text { Land project }\end{array}$ & 9 & $\begin{array}{l}\text { Farmers taking part in Farmers Heal the Land; } \\
\text { two males, three females, and two couples } \\
\text { (husband main respondent). All had been in the } \\
\text { project for }>14 \text { years, except one, who started } \\
\text { in } 2006\end{array}$ & $\begin{array}{l}\text { Involved in project }>5 \text { years, from } \\
\text { different parts of Iceland, gender } \\
\text { balance }\end{array}$ \\
\hline $\begin{array}{l}\text { Members of the Hekluskógar } \\
\text { collaboration committee }\end{array}$ & 9 & $\begin{array}{l}\text { Two representatives from SCSI, six from other } \\
\text { governmental and nongovernmental } \\
\text { organizations, one from local farmers. Current } \\
\text { project manager }\end{array}$ & $\begin{array}{l}\text { Member of the collaboration } \\
\text { committee at some time during the } \\
\text { collaboration phase (2005-2007) }\end{array}$ \\
\hline
\end{tabular}

attain governmental funding. Furthermore, the SCSI and fellow committee members alike expected the collaboration committee to contribute to project design. The SCSI staff expressed satisfaction with the project and also saw what they called the "Hekluskógar model"-using clusters of native species as seed sources for reclaiming trees and shrubs on large areas-as a potential model for other projects. The collaboration partners seemed to have developed a deep interest in the project and were satisfied with it as such, although some of them expressed strong disappointment over expectations that were not met. One such expectation was that the project would generate increased funding for the forestry sector, but according to some interviewees, a portion of governmental funding to other forestry projects was rechanneled to Hekluskógar. Several stakeholders were also disappointed because the final Hekluskógar arrangements (Table 2) did not involve continued multi-stakeholder management, as they had expected.

Statements of some of the SCSI staff denoted that, to them, participation meant literally that other stakeholders participated in activities such as tree planting and environmental education.

\section{Influence and control}

The SCSI staff controlled the overall design and administration of FHL, while the farmers decided whether to join the project and made decisions about activities on their own land. They also hosted the district officer visits, while the visit schedule, duration, and examination of restoration plots was decided by the district officers. The district officers said they continually tried to improve FHL, but except for requests for feedback when the project started, statements of district officers and farmers indicated that farmers had little influence on project arrangements. This lack of influence was one of the few things farmers complained about. Many of them had either suggested changes to no avail or had ideas for improvement that they had not communicated.

The core idea of the Hekluskógar project was developed within the SCSI before involving other stakeholders, and it stayed essentially unchanged through the participatory process. During the collaboration phase, the collaboration committee decided about project arrangements, although one nongovernmental organization interviewee stated that "the scientists carried the final responsibility." Many interviewees described how the committee members strongly disagreed on some points, especially about what species to use, but after deliberation, they settled on the SCSI's original idea to use only native species because "it was considered most likely to succeed, financially."

The committee suggested continued collaborative management of the final Hekluskógar project (Hekluskógar Collaboration Committee 2005), but in the end it was decided, at the governmental level, to make the SCSI and Iceland Forest Service responsible for its implementation (Table 2). In the Hekluskógar contract from 2007, the collaboration committee was assigned an advisory role during project implementation, but in reality, committee meetings became less and less frequent (Table 2). One committee member put it like this:

"[T]his project was simply stolen out of the hands of the grassroots... And when that happened, then the original Hekluskógar model, about this powerful collaboration, it was just done with."

The same person believed that this course of events ruined Hekluskógar's potential for being a participation role model. 
Table 4. Aims, expectations, and outcomes of Farmers Heal the Land, mentioned by interviewed Soil Conservation Service of Iceland (SCSI) staff and participating farmers.

\begin{tabular}{|c|c|c|c|}
\hline \multicolumn{2}{|c|}{ SCSI staff } & \multicolumn{2}{|c|}{ Farmers } \\
\hline Aims and expectations ${ }^{\dagger}$ & Outcomes $^{*}$ & Aims and expectation ${ }^{\dagger}$ & Outcomes $^{\ddagger}$ \\
\hline $\begin{array}{l}\text { Activate landowners and others to } \\
\text { attend to soil conservation. Change } \\
\text { attitudes }\end{array}$ & $\begin{array}{l}\text { Landowners show more interest in } \\
\text { soil conservation. Care about the land. } \\
\text { Change of attitude }\end{array}$ & More land for grazing ${ }^{\S}$ & $\begin{array}{l}\text { Have more grazing now, higher } \\
\text { economic returns, increased land } \\
\text { value }\end{array}$ \\
\hline $\begin{array}{l}\text { Increase others' knowledge about soil } \\
\text { conservation. Educate others }\end{array}$ & $\begin{array}{l}\text { Landowners and others have learned } \\
\text { and gained more skills and } \\
\text { understanding about soil conservation }\end{array}$ & $\begin{array}{l}\text { Improve condition and/or sight of } \\
\text { land, stop erosion }\end{array}$ & $\begin{array}{l}\text { Improved condition/sight of land. } \\
\text { Larger area vegetated than before }\end{array}$ \\
\hline Cost-efficiency & $\begin{array}{l}\text { Cost-efficiency. Landowners } \\
\text { contribute more than agreed on in } \\
\text { contract }\end{array}$ & $\begin{array}{l}\text { Decrease grazing impact on other } \\
\text { land }\end{array}$ & $\begin{array}{l}\text { Protects sensitive land from grazing. } \\
\text { Controls grazing }\end{array}$ \\
\hline $\begin{array}{l}\text { Ownership. Landowners take } \\
\text { responsibility for conservation and } \\
\text { state of land }\end{array}$ & $\begin{array}{l}\text { Farmers demonstrate ownership of } \\
\text { own conservation project } \\
\text { Landowners monitor and maintain } \\
\text { results } \\
\text { Better, less destructive grazing } \\
\text { regimes }\end{array}$ & Prepare land for growing trees & $\begin{array}{l}\text { Have land for trees, have planted } \\
\text { trees }\end{array}$ \\
\hline $\begin{array}{l}\text { Improve relationship between SCSI } \\
\text { and farmers. Gain mutual } \\
\text { understanding }\end{array}$ & $\begin{array}{l}\text { Improved relationship between SCSI } \\
\text { and farmers } \\
\text { Increased local acceptance of SCSI }\end{array}$ & & $\begin{array}{l}\text { Improved relationship between SCSI } \\
\text { and farmers }\end{array}$ \\
\hline SCSI learning from others & SCSI has learned from farmers & & $\begin{array}{l}\text { Have learned from district officers } \\
\text { Have personally gained more } \\
\text { understanding/skills/ } \\
\text { experience in soil conservation } \\
\text { Have personal interest in soil } \\
\text { conservation and state of the land. } \\
\text { Experiments with revegetation } \\
\text { methods by own initiative }\end{array}$ \\
\hline \multirow[t]{4}{*}{$\begin{array}{l}\text { Higher quality and sustainability of } \\
\text { results }\end{array}$} & Sustainability of results & & $\begin{array}{l}\text { Monitors and maintains revegetation } \\
\text { results. Proud of results } \\
\text { Personally contributes more than } \\
\text { agreed on in contract }\end{array}$ \\
\hline & $\begin{array}{l}\text { Image of SCSI and farmers more } \\
\text { positive }\end{array}$ & & $\begin{array}{l}\text { Image of SCSI and farmers more } \\
\text { positive }\end{array}$ \\
\hline & $\begin{array}{l}\text { Revegetation results "contagious". } \\
\text { Other farmers become interested }\end{array}$ & & $\begin{array}{l}\text { Neighbors have become interested } \\
\text { by seeing results }\end{array}$ \\
\hline & $\begin{array}{l}\text { Landowners have gained. More } \\
\text { grazing, higher economic returns }\end{array}$ & & \\
\hline $\begin{array}{l}\text { Aims and expectations with participat } \\
\text { frequency is just an indication and is n } \\
\text { ॠ We use the word outcome in a broad } \\
\text { activities. } \\
{ }^{\S} \text { Mentioned by all interviewed farmers }\end{array}$ & $\begin{array}{l}\text { ion in descending order after frequenc } \\
\text { ot statistically significant. } \\
\text { sense, meaning perceived changes, be } \\
\end{array}$ & $\begin{array}{l}\text { in interviews. Due to the semi-str } \\
\text { fits-or losses—and other end re }\end{array}$ & $\begin{array}{l}\text { ed nature of the interviews, the } \\
\text { material or nonmaterial, of project }\end{array}$ \\
\hline
\end{tabular}

People elsewhere would be reluctant to engage themselves in similar projects because the government might take over and exclude them.

\section{Interaction}

Interaction, especially face-to-face, was an integral part of both projects. It relied mainly on common communication skills and received little formal planning or training. Nevertheless, all interviewee groups found it mostly positive and constructive. Parallel with the launching of FHL, the SCSI started to establish district offices in different parts of the country in order to, as one SCSI official said, "...move our operations closer to the people and build stronger bridges to the locals." 
A yearly visit to participating farms was a key component of FHL. The visits were informal and offered opportunities to talk about soil conservation matters, something farmers rarely discuss among themselves according to many interviewed farmers:

"[W]hen farmers meet... soil conservation is not the main subject on the agenda even though it is a large part of our daily tasks."

Farmers and district officers alike talked about mutual exchange of knowledge and experiences during these encounters, and said that the officers carried knowledge both to farmers and between them. Both parties considered conversations about other unrelated issues-often over a cup of coffee-to be important and said that they contributed to friendly relations. The district officers occasionally contacted farmers in between visits, and sent FHL newsletters annually. Farmers, however, said that they seldom contacted the SCSI by their own initiative-something district officers complained about-but many of them felt welcome to do so if they wished. The SCSI staff revealed that they tried to facilitate more spontaneous contacts by moving their district offices to buildings housing other organizations sought by farmers.

Governmental agencies in Iceland have undergone substantial budget cuts since the country underwent a financial crisis in 2008. One of the SCSI's cost reducing measures was to decrease visits to some FHL farmers to every second year. At the same time, and despite increased fertilizer prices, the average subsidized quantity of fertilizer per farm was maintained. The interviewed farmers who did not get annual visits complained about this lack of contact. Some also complained about frequent changes of district officers and not knowing who their contact person was or even what district office they belonged to.

The Hekluskógar participatory process was improvised along the way. During the collaboration phase, the collaboration committee usually met monthly, and committee members stayed in contact between meetings. All interviewees experienced this period as positive. Meetings were described as informal and friendly, although they also involved heated discussions. All interviewees said they felt free to express themselves and usually felt listened to, but some representatives of local organizations occasionally felt that their ideas were not taken into consideration. After formal establishment of the project in 2007, collaboration committee meetings should be called twice a year. This was initially adhered to, but then meetings became scarcer (Table 2). Committee members with no other connection to the project at this stage expressed strong disappointment about this lack of involvement. They personally wanted to stay involved, but one of them also saw this as a risk for the project:
"[I]t is not enough to involve the grass-root, you also have to nourish it... for example by continuing the committee meetings... [The grass-root] thrives on information... And in the end, it is the grass-root that obtains the [project] funding."

Two SCSI interviewees also mentioned that the committee was not kept involved, and one of them was worried that this would have negative consequences for the project.

\section{Ability and commitment of the Soil Conservation Service of Iceland}

Both the SCSI staff and one farmer mentioned that the SCSI had changed from doing mostly practical conservation work to focusing more on research, advisory activities, and supporting others' restoration work. SCSI respondents had either agricultural or natural science education, and only a couple of them had any kind of formal training related to participation. They all expressed interest in these approaches and found them valuable, but the participatory processes were not formally evaluated.

The district officers said they received little introduction to the communication part of their work, usually only a few farmer visits together with an experienced colleague. They got sporadic communication courses, but no formal communication guidelines existed. Participant observations and interviews with farmers showed, however, that the district officers were able communicators. They described how they support each other and discuss communication matters, especially when there are difficulties. Some of them expressed concern about limited connection with the SCSI research division, and about low priority of participatory projects within the SCSI; many colleagues did not acknowledge the value and importance of such projects, and the district officers felt they sometimes had to defend them, including the need for spending money on farm visits. They also mentioned problems with lack of time, and farmers were also aware of this. In 2010, the cost of FHL was $9.4 \%$ of the SCSI's total expenses, while the project accounted for $44 \%$ of the revegetation (in hectares) performed or supported by the SCSI that year (Jónsson 2010, SCSI 2010).

The SCSI staff members organizing the Hekluskógar process had no prior experience of conducting participatory processes, but other stakeholders' statements indicated that they were competent communicators. The agency also seemed to have spent ample resources on the project during the collaboration phase. The interviews, however, revealed some problems with being open to uncertain outcomes. A recount of the first Hekluskógar collaboration meeting illustrates this:

"[When we] tried to sell them our idea, we got all kinds of reactions... and I got the feeling that, 'damn, now they will destroy our project... and this was such a great project... maybe we should just have done it by ourselves'.... But I'm so glad we continued... because this is the only way to realize such a large project, to let many parties buy it." 


\section{DISCUSSION}

The interviews gave a picture of a predominant product focus at the SCSI. The main indicator was that the SCSI interviewees expressed primarily pragmatic aims and expectations with involving other stakeholders. The antagonism between farmers and the SCSI used to be a limiting factor for soil conservation in Iceland, so the wishes for improved relationships could also be seen as pragmatic (cf. Reed 2008). The SCSI staff and some Hekluskógar partners seemed to have somewhat diverging understandings of the collaboration initiative (cf. Moore 1996). The SCSI's main objective with inviting other stakeholders was to realize the project idea, that is, product oriented. The partners also wanted the project to come true, but in addition they expected collaborative management of the future project, i.e., a process-oriented objective. That the SCSI interviewees used the "Hekluskógar model" concept in an ecological and pragmatic sense, while one collaboration partner used it to refer to the collaboration initiative, supports this interpretation.

Some farmers' and Hekluskógar partners' expectations seemed to have developed during, and as a result of, the participatory processes themselves. These expectations were mainly about influence and interaction, which is in line with Moore's (1996) observations that expectations can be directly related to how participatory processes are conducted and experienced. In our case studies, most of the unmet expectations were process related. The SCSI staff did not seem well aware that aims and expectations with participation can be process related or that the processes themselves might generate expectations that need attention.

A common discourse at the SCSI was that land users should take more responsibility for soil conservation matters. Still, while other stakeholders had a certain influence over practical issues in both projects, it can be said that the SCSI and the Icelandic government retained the overall control. The apparent power asymmetry was evident mostly at a structural and institutional level. On a personal level, all stakeholders seemed on equal terms, which is the common way of relating in Iceland. In FHL, there was no formal procedure for farmers to influence project arrangements. The Hekluskógar collaboration committee had significant influence during the collaboration phase, but the administrative arrangements of the final project, decided at a governmental level, ignored the committees' suggestions of continued collaborative management and put two governmental agencies in charge of project implementation (cf. Arnstein 1969). During the collaboration period, the image of a "grass-root" project was considered likely to create political support for the idea (cf. Arnstein 1969, Mosse 2001), but with the final project arrangements, the "grass-roots" were practically excluded from having genuine influence on the project. This could be a sign of reluctance to release control (cf. Campbell 1994, Pretty 1995) and commit to the shared influence implicit in participatory processes (cf. Warburton 1997, Buchy and Hoverman 2000, Reed 2008). Furthermore, this example illustrates how political and institutional structures can constrain governmental agencies in their attempts to use participatory approaches.

Face-to-face interaction between the SCSI representatives and other stakeholders was a key factor for creating outcomes in both projects (cf. Warburton 1997, Bentrup 2001, Rowe and Frewer 2005). In FHL, an annual visit seemed sufficient as long as it was consistent, and in Hekluskógar, the intensive contact during the collaboration phase contributed to the collaboration partners' strong "ownership" of the project (cf. Warburton 1997, Senecah 2004). Campbell (1994:15) suggested that the general lack of training in "people skills" creates problems for professionals involved in participatory projects. In our case studies, this was not so evident at the faceto-face level, where common social skills seemed enough in most cases. Instead, dissatisfaction occurred when interaction with other stakeholders was reduced or the contact became inconsistent and unpredictable. This suggests that the problem was rather related to limited knowledge about the crucial role of interaction in participatory projects, which might be ascribed to lack of training.

Participation usually requires environmental agencies to change and develop new institutional cultures (Campbell 1994, Pretty 1995, Warburton 1997, Reed 2008). Several interviewees stated that the SCSI has indeed changed since they started to involve other stakeholders. Nevertheless, the need to defend the use of resources on participatory projects, felt by some district officers, and the lack of connection between them and the SCSI research division may be a sign that participation was not fully integrated within the agency culture (cf. Reed 2008).

\section{Interpretation of participation and effect on practice}

From our analysis we draw the conclusion that participation was seen mainly as a method to accomplish the SCSI's own goals effectively by engaging others to, literally, "participate" in soil conservation activities. Their interpretation of participation encompassed considerable interaction with other stakeholders but involved very limited requirements on themselves to release overall control and build capacity in communication and participation. This understanding of participatory approaches resembles what Pretty (1995) calls functional participation, or participation as a method to fulfill the initiators' goals. Functional participation might be interactive, but the processes allow for only minor decisions, while the authorities make the major decisions, often based on predetermined objectives. FHL also bears some resemblance to what Pretty (1995) defines as participation for incentives. Contrary to FHL, however, participation for incentives does not involve learning, farmers' experimentation, and sustainability of practice. It can even be argued that FHL 
does not qualify as participation because of its individually based partnership structure, but the scope of our study does not allow conclusions about that.

Tangible outputs are essential for participatory projects (Moore et al. 2001), so product focus is relevant and necessary for governmental agencies that have certain duties to fulfill (Warburton 1997). Furthermore, the SCSI is well known in Iceland, so the other stakeholders were familiar with their role and overall objectives before they joined the projects. By and large, the soil conservation and revegetation outputs of the two projects matched the interests of the SCSI and the other interviewees, although they expressed somewhat different reasons for wanting them. There were also other gains, such as improved trust and relations (cf. Buchy and Hoverman 2000, Senecah 2004), and joint production of knowledge that stemmed from the interaction between district officers and farmers (cf. Pretty 1995, Buchy and Hoverman 2000). The lack of mechanisms in FHL to systematically record and disperse this knowledge might, however, indicate that the extent of it was unanticipated. We conclude that the product focus contributed to considerable gains in these projects.

The FHL farmers and Hekluskógar partners were mostly satisfied with the projects, but some of them also complained about lack of influence and interaction, and other unmet expectations. This suggests that the agency's product focus worked well as long as there were perceived joint gains (Pretty 1995, Warburton 1997, Beierle 2002) and adequate attention to process factors such as interaction (Pretty 1995, Beierle 2002, Rowe and Frewer 2005) and shared influence (Arnstein 1969, Pretty 1995). But when these aspects were not attended to, dissatisfaction occurred among some stakeholders. Other scholars have observed similar problems when process factors were not sufficiently considered, e.g., discontent (Senecah 2004), exaggerated stakeholder expectations, and limited stakeholder inputs (Buchy and Hoverman 2000). It may also negatively affect trust and relationships (Pretty 1995, Senecah 2004), and render outcomes unsustainable (Pretty 1995, Warburton 1997). Ultimately, this means potential loss of benefits (Buchy and Hoverman 2000), which highlights the need to view participation not only as a means to an end but also as a process (cf. Warburton 1997).

The emerging picture is that, even though successful in achieving tangible results, particularly the agency's own goals, the SCSI's product focus might have led to limited attention to process and people-related factors and little sensitivity to other stakeholders' expectations that did not correlate with the SCSI's own. This had some negative consequences in our case studies and might have limited the effectiveness of the SCSI's participatory approaches. Relatively low priority of training in communication and in conducting participatory processes could also be a consequence of product focus (cf. Campbell 1994).
It is pertinent for environmental agencies to emphasize tangible outputs of participatory projects, and this study showed that in many ways, the SCSI's interpretation of participation was effective in dealing with complex soil conservation issues. But it also showed that it is important to consider, and balance, both product and process aspects to optimize the effectiveness of participatory approaches. For agency personnel with agricultural and environmental science background, product aspects may be easier to deal with than process aspects, which are generally just as complex as biophysical matters. This highlights the necessity for thorough knowledge and understanding of participation and thus for providing agency staff with training and education in participation and communication. To further facilitate participatory approaches, efforts should be made to integrate this understanding within the agencies and also within the institutional frameworks in which they operate. We argue that this will enhance participatory processes and, ultimately, benefit land restoration and other forms of environmental management.

Responses to this article can be read online at: http://www.ecologyandsociety.org/issues/responses. php/5516

\section{Acknowledgments:}

Landsvirkjun's Energy Research Fund provided financial support for this study. The authors would like to thank all interviewees and the Soil Conservation Service of Iceland for their willingness to participate in the study, and Karl Benediktsson for valuable feedback.

\section{LITERATURE CITED}

Aradóttir, Á. L. 2007. Restoration of birch and willow woodland on eroded areas. Pages 67-74 in G. Halldorsson, E. S. Oddsdottir, and O. Eggertsson, editors. Effects of afforestation on ecosystems, landscape and rural development. TemaNord 2007:508, 18-22 June 2005, Reykholt, Iceland. [online] URL: http://www.norden.org/en/ publications/publikationer/2007-508/at_download/publicationfile

Arnalds, A. 2005. Approaches to landcare—a century of soil conservation in Iceland. Land Degradation \& Development 16(2):113-125. [online] URL: http://onlinelibrary.wiley.com/ doi/10.1002/ldr.665/abstract http://dx.doi.org/10.1002/ldr.665

Arnstein, S. R. 1969. A ladder of citizen participation. Journal of the American Institute of Planners 35(4):216-224. [online] URL: http://dx.doi.org/10.1080/01944366908977225 
Barkarson, B. H., and M. H. Johannsson. 2009. Arctic landcare. Pages 55-63 in D. Catacutan, C. Neely, M. Johnson, H. Poussard, and R. Youl, editors. Landcare: local actionglobal progress. World Agroforestry Centre, Nairobi, Kenya.

Beierle, T. C. 2002. The quality of stakeholder-based decisions. Risk Analysis 22(4):739-749. [online] URL: http:// onlinelibrary.wiley.com/doi/10.1111/0272-4332.00065/full

Bentrup, G. 2001. Evaluation of a collaborative model: a case study analysis of watershed planning in the intermountain west. Environmental Management 27(5):739-748. [online] URL: http://www.springerlink.com/content/071d65gjvduevrva/

Blumer, H. 1969. Symbolic interactionism: perspective and method. Prentice-Hall, Englewood Cliffs, New Jersey, USA.

Boeije, H. 2010. Analysis in qualitative research. SAGE, London, UK.

Brynleifsdóttir, S. J. 2011. Baendur graða landið. Ársskýrsla 2011. LR-2012/13. Soil Conservation Service of Iceland, Gunnarsholt, Iceland. [online] URL: http://www.land.is/ images/pdf-documents/arsskyrslur/bgl_skyrslur/bgl-skyrsla.pdf

Buchy, M., and S. Hoverman. 2000. Understanding public participation in forest planning: a review. Forest Policy and Economics 1:15-25. http://dx.doi.org/10.1016/S1389-9341 (00)00006-X

Buzan, T., and B. Buzan. 2006. The mind map book. BBC Active, Harlowe, Essex, UK.

Campbell, A. 1994. Community first: landcare in Australia. Gatekeeper Series SA42. International Institution for Environment and Development, London, UK.

Convention on Biological Diversity. 1992. United Nations Environment Programme. [online] URL: http://www.cbd.int/ convention/text/

Farmers Association of Iceland. 2010. Hagtölur landbúnaðarins 2010. [online] URL: http://www.sjavarutvegsraduneyti.is/ media/Skyrslur/Hagtolur landbunadarins 2010.pdf

Hekluskógar. 2007. [online] URL: http://www.hekluskogar. is/2007.htm

Hekluskógar Collaboration Committee. 2005. Hekluskógar. Endurheimt skóglenda í nágrenni Heklu. Forsendur og leiðir. [online] URL: http://hekluskogar.is/Skjol/hekluskog12okt. pdf

Jónsson, J. B. 2009. Bandur graða landið. Framkvamd verkefnisins árið 2009. LR-2009/18. Soil Conservation Service of Iceland, Gunnarsholt, Iceland. [online] URL: http:// www.land.is/images/pdf-documents/arsskyrslur/bgl skyrslur/ Arsskyrsla_BGL_2009.pdf

Jónsson, J. B. 2010. Bändur graða landið. Framkvaemd verkefnisins árið 2010. LR-2010/20. Soil Conservation
Service of Iceland, Gunnarsholt, Iceland. [online] URL: http://www.land.is/images/pdf-documents/arsskyrslur/bgl skyrslur/ Arsskyrsla BGL 2010.pdf

Kvale, S. 1996. Interviews: an introduction to qualitative research interviewing. SAGE, Thousand Oaks, California, USA.

Lög um landgræðslu no. 17/1965. [online] URL: http://www. althingi.is/lagas/nuna/1965017.html

Michener, V. 1998. The participatory approach: contradiction and co-option in Burkina Faso. World Development 26 (12):2105-2118. http://dx.doi.org/10.1016/S0305-750X(98) 00112-0

Moore, S. A. 1996. Defining "successful" environmental dispute resolution: case studies from public land planning in the United States and Australia. Environmental Impact Assessment Review 16(3):151-169. http://dx.doi. org/10.1016/0195-9255(96)00048-0

Moore, S. A., S. Jennings, and W. H. Tacey. 2001. Achieving sustainable natural resource management outcomes on the ground: the key elements of stakeholder involvement. Australian Journal of Environmental Management 8(2):9198. http://dx.doi.org/10.1080/14486563.2001.10648517

Mosse, D. 2001. 'People's knowledge', participation and patronage: operations and representations in rural development. Pages 16-35 in B. Cooke and U. Kothari, editors. Participation: the new tyranny? Zed Books, London, UK.

Pretty, J. N. 1995. Participatory learning for sustainable agriculture. World Development 23(8):1247-1263. http://dx. doi.org/10.1016/0305-750X(95)00046-F

Reed, M. S. 2008. Stakeholder participation for environmental management: a literature review. Biological Conservation 141:2417-2431. http://dx.doi.org/10.1016/j.biocon.2008.07.014

Rowe, G., and L. J. Frewer. 2005. A typology of public engagement mechanisms. Science, Technology, \& Human Values 30(2):251-290. http://dx.doi.org/10.1177/0162243904271724

Senecah, S. L. 2004. The trinity of voice: the role of practical theory in planning and evaluating the effectiveness of environmental participatory processes. Pages 13-33 in S. P. Depoe, J. W. Delicath, and M-F. A. Elsenbeer, editors. Communication and public participation in environmental decisionmaking. State University of New York Press, Albany, New York, USA.

Soil Conservation Service of Iceland (SCSI). 2010. Ársskýrsla Landgraðsla ríkisins 2010. Soil Conservation Service of Iceland, Gunnarholt, Iceland. [online] URL:

http://www.land.is/images/pdf-documents/arsskyrslur/ Arsskyrsla 2010-1r.pdf 
Soil Conservation Service of Iceland (SCSI). 2012. History of the Soil Conservation Service of Iceland. [online] URL: http:// www.land.is/english/history-of-scsi

Stenseke, M. 2009. Local participation in cultural landscape maintenance: lessons from Sweden. Land Use Policy 26:214223. [online] URL: http://dx.doi.org/10.1016/j.

landusepol.2008.01.005

Stringer, L. C., A. J. Dougill, E. Fraser, K. Hubacek, C. Prell, and M. S. Reed. 2006. Unpacking "participation" in the adaptive management of social-ecological systems: a critical review. Ecology and Society 11(2):39. [online] URL: http:// www.ecologyandsociety.org/vol11/iss2/art39

United Nations Economic Commission for Europe (UNECE). 1998. Convention on access to information, public participation in decision-making and access to justice in environmental matters (Aarhus convention). [online] URL: http://www.unece.org/fileadmin/DAM/env/pp/documents/cep43e. pdf

Warburton, D. 1997. Participatory action in the countryside. A literature review. Countryside Commission, Cheltenham, UK.

Westberg, L., L. Hallgren, and A. Setterwall. 2010. Communicative skills development of administrators: a necessary step for implementing participatory policies in natural resource management. Environmental Communication: A Journal of Nature and Culture. 4(2):225-236. http://dx.doi. org/10.1080/17524031003755309 